Zeszyty Naukowe Szkoły Głównej Gospodarstwa Wiejskiego

Ekonomika i Organizacja Gospodarki Żywnościowej nr 121 (2018), 55-70

DOI 10.22630/EIOGZ.2018.121.4

Katarzyna Kita D

Wydział Ekonomiczno-Społeczny

Uniwersytet Przyrodniczy w Poznaniu

\title{
Zmiany samowystarczalności żywnościowej wybranych krajów azjatyckich
}

\begin{abstract}
Abstrakt: Celem artykułu jest określenie zmian poziomu samowystarczalności żywnościowej w krajach ASEAN, definiowanej jako relacja między krajowym zużyciem a produkcją z wyodrębnieniem konsumpcji poszczególnych artykułów rolno-spożywczych. Z uwagi na uwarunkowania historyczne, geograficzne i kulturowe ryż jest w centrum zainteresowania rządów krajów ASEAN. Tylko w Tajlandii, Wietnamie i Kambodży wskaźnik samowystarczalności przewyższał 100\%. Z kolei we wszystkich krajach członkowskich produkcja zaspokajała potrzeby rynku wewnętrznego w zakresie roślin cukrodajnych. Stosunkowo największe braki w produkcji odnotowano w odniesieniu do mleka. Zaobserwowano także wzrost spożycia produktów rolno-spożywczych zarówno pochodzenia roślinnego (z wyjątkiem zbóż, roślin okopowych), jak i zwierzęcego. Przy czym większą dynamiką charakteryzowała się konsumpcja tych ostatnich. Odnotowany rosnący popyt na produkty pochodzenia zwierzęcego jest efektem szybkiego rozwoju społeczno-gospodarczego krajów ASEAN, w ślad za którym następują zmiany w strukturze konsumpcji żywności w kierunku wzorców obserwowanych w krajach rozwiniętych.
\end{abstract}

Słowa kluczowe: samowystarczalność żywnościowa, spożycie produktów rolno-żywnościowych, ryż, ASEAN

Kody JEL: D12, Q11, O10, O57

\section{Wstęp}

Pojęcie samowystarczalności żywnościowej można rozpatrywać w kontekście zamkniętej i otwartej gospodarki. W pierwszym przypadku mamy do czynienia z sytuacja, w której zapotrzebowanie na żywność rynku wewnętrznego pokrywane jest

Katarzyna Kita (D https://orcid.org/0000-0001-7146-2075

『kita@up.poznan.pl, UPP, WES, ul. Wojska Polskiego 28, 60-637 Poznań 
z produkcji krajowej (co jest niejako równoznaczne z „samozaopatrzeniem”) [Kwasek 2009, Gulbicka i in. 2015]. Z kolei w drugim (oznaczającym specjalizację i szeroko rozwinięte kontakty handlowe) samowystarczalność należy rozumieć jako zdolność całej gospodarki do pokrycia popytu na podstawowe produkty rolno-spożywcze rodzimą produkcją oraz uzupełnienie/wzbogacanie asortymentu żywności importem $^{1}$ [ Mikuła 2012, Baer-Nawrocka 2014].

Samowystarczalność żywnościowa zazwyczaj identyfikowana jest z bezpieczeństwem żywnościowym, ale go nie gwarantuje [Clapp 2017]. Oba pojęcia uzupełniają się wzajemnie, przy czym, o ile w koncepcji samowystarczalności żywnościowej akcent jest położony przede wszystkim na optymalne wykorzystanie zdolności produkcyjnych gospodarki żywnościowej w celu zaopatrzenia społeczeństwa w produkty rolno-spożywcze, o tyle w drugim uwaga jest skierowana także na sferę popytową (poziom, struktura, zdrowotna jakość spożywanej żywności, bez względu na status ekonomiczny gospodarstwa domowego $)^{2}$ [Kapusta 2016].

Pojęcie samowystarczalności żywnościowej jako elementu bezpieczeństwa żywnościowego stało się przedmiotem szerokiej dyskusji na arenie międzynarodowej w czasie kryzysu żywnościowego z lat 2007-2008, kiedy to wiele krajów, chcąc odizolować się od wpływu niestabilnych cen żywności na swoich rynkach wewnętrznych, uznała samowystarczalność w zakresie żywności za priorytet - nie tylko gospodarczy, ale i polityczny. Propagowanie powrotu do polityki wysokiego poziomu samowystarczalności osiaganej przez pokrycie zużycia żywności jej produkcją

\footnotetext{
${ }^{1}$ Miarą tak rozumianej samowystarczalności żywnościowej jest m.in. saldo bilansu handlowego w sektorze rolno-spożywczym. Należy jednak mieć na uwadze, że opieranie się na imporcie może też przyczyniać się do zmniejszenia stopnia krajowego bezpieczeństwa żywnościowego, zwłaszcza w kontekście zmian klimatu, niestabilności i spekulacji na globalnym rynku żywności oraz presji ze strony rozwijających się gospodarek [Gulbicka 2009].

${ }^{2}$ Według oficjalnej definicji sformułowanej na Światowej Konferencji Żywnościowej w 1974 roku w Rzymie bezpieczeństwo żywnościowe należy rozumieć jako dostarczanie w każdym czasie odpowiedniej ilości podstawowych produktów żywnościowych w celu zaspokojenia rosnącej konsumpcji oraz przeciwdziałania fluktuacjom wielkości produkcji oraz cen [Kraciuk 2015]. Z biegiem czasu zakres tej koncepcji rozszerzono o stronę popytową i kwestie bezpiecznej żywności na różnych poziomach - gospodarstwa domowego, regionalnym i narodowym. Organizacja Narodów Zjednoczonych ds. Wyżywienia i Rolnictwa uwzględnia cztery wymiary bezpieczeństwa żywnościowego: dostępność żywności (ang. food availability) - zapewnienie wystarczającej podaży żywności w kraju, bez względu na jej pochodzenie; dostęp fizyczny i ekonomiczny do żywności (ang. food access) - dostęp do żywności dla całego społeczeństwa, w tym dla najsłabszych ekonomicznie gospodarstw; możliwości wykorzystania (ang. food utilization) - zapewnienie zbilansowanej racji pokarmowej żywności o wysokiej jakości, która nie stanowi zagrożenia dla zdrowia i życia człowieka; stabilność systemu w czasie (ang. food stability) - zapewnienie dostępu do żywności przez cały czas zarówno na poziomie populacji, jak i gospodarstwa domowego czy jednostki: nikt nie powinien utracić dostępu do żywności z powodu gwałtownych zdarzeń losowych [FAO 2008]. W tym ujęciu samowystarczalność żywnościowa oznacza dostępność ekonomiczną i fizyczną żywności na rynku krajowym niezależnie od tego, skąd ta żywność pochodzi [Małysz 2008, Sapa 2010].
} 
wewnątrz kraju ma szczególne znaczenie w przypadku Azji z dwóch powodów. Po pierwsze spośród około $815 \mathrm{mln}$ osób na świecie, które według FAO są niedożywione, aż 63\% mieszka w krajach regionu Azji [FAO 2017]. W przypadku krajów Stowarzyszenia Azji Południowo-Wschodniej (ASEAN) liczba osób pozostających w niedożywieniu jest szacowana na $60 \mathrm{mln}$, a odsetek tej populacji w poszczególnych krajach członkowskich jest zróżnicowany i kształtuje się na poziomie od 5 (Malezja i Brunei) do $18 \%$ (Laos) ${ }^{3}$. Po drugie dla znacznej części mieszkańców krajów tego ugrupowania (ale i innych krajów regionu) ryż był i nadal pozostaje podstawowym składnikiem diety, a wszelka niestabilność cenowa tego towaru ${ }^{4}$ przyczynia się do pogorszenia ich sytuacji wyżywieniowej ${ }^{5}$.

Z gospodarczego punktu widzenia kraje członkowskie $\mathrm{ASEAN}^{6}$ można podzielić na trzy grupy ${ }^{7}$ [Bello 2005]. Każda z nich ma wiele cech specyficnych i każda reprezentuje odmienne możliwości w zakresie realizacji bezpieczeństwa żywnościowego. Singapur i Brunei są liderami w zakresie dostępności żywności i dostępu do żywności (ekonomicznego i fizycznego) ${ }^{8}$. Oba kraje charakteryzują się względnie niewielką populacją (odpowiednio powyżej 5,5 mln oraz $0,41 \mathrm{mln}$ mieszkańców), wysokim PKB per capita (między 74,5 tys. a 80 tys. USD ${ }^{9}$ ) oraz marginalnym znaczeniem sektora rolnego (poniżej 1\% PKB). Do drugiej grupy zaliczyć można kraje, które transformacji gospodarczej dokonały w latach 70. (Malezja, Tajlandia) i 80. XX wieku (Wietnam) i które realizując prorynkową i proeksportową strategię rozwoju gospodarczego, są obecnie zaliczane do jednych z najszybciej rozwi-

\footnotetext{
${ }^{3}$ World Bank database, http://databank.worldbank.org/data/reports.aspx?source=2\&country=AUS\#sel ectedDimension_DBList [dostęp: 22.03.2017].

${ }^{4} \mathrm{~W}$ latach $2006-2008$ średnie ceny ryżu na świecie wzrosły o $217 \%$, pszenicy o $136 \%$, kukurydzy o $125 \%$ i soi o $107 \%$.

${ }^{5} \mathrm{~W}$ celu złagodzenia wpływu fluktuacji cenowych żywności i poprawy sytuacji dochodowej krajowych konsumentów rządy państw członkowskich ASEAN podjęły wiele działań z zakresu polityki budżetowej i handlowej [Arnst 2009, Malchar-Michalska 2012].

${ }^{6}$ Więcej o ASEAN [Nosecka i in. 2012].

${ }^{7}$ Podział ten odnosi się przede wszystkim do teorii „klucza lecących gęsi”, zgodnie z którą gospodarki słabiej rozwinięte „doganiają” lepiej i szybciej rozwijające się kraje regionu. Pierwowzorem była Japonia doganiająca Europę Zachodnią. Obecnie to szybko rozwijające się kraje Azje próbują dogonić Japonię [Żyła 2013].

${ }^{8}$ Przy czym oba kraje praktycznie w całości zależne są od dostaw żywności z zewnątrz. Singapur wytwarza jedynie $10 \%$ żywności dostępnej na rynku wewnętrznym, a pozostała jej pochodzi z importu. Mimo to wysoki poziom rozwoju społeczno-gospodarczego i odpowiednia polityka (m.in. dywersyfikacja dostawców, bardzo niskie stawki celne $\mathrm{w}$ ramach $\mathrm{KNU}$, negocjacje handlowe $\mathrm{z}$ innymi krajami) sprawiły, że od wielu lat w klasyfikacji światowego indeksu bezpieczeństwa żywnościowego (ang. Global Food Security Index) opracowywanego przez Economist Intelligence Unit kraj ten plasuje się w czołówce. W 2017 roku zajął czwarte miejsce (za Irlandią, USA i Wielką Brytanią) i jednocześnie był liderem w regionie w kwestii bezpieczeństwa żywnościowego [Economist Intelligence Unit, http:// foodsecurityindex.eiu.com/Country/Details\#Singapore; dostęp: 10.12.2017].

${ }^{9}$ USD, ceny stałe z 2011 roku, według parytetu siły nabywczej.
} 
jających się na świecie ${ }^{10}$. O ile jednak w Malezji i Tajlandii zaobserwowano spadek udziału rolnictwa w tworzeniu PKB (w 2015 r. było to odpowiednio 9 i 6,7\%), o tyle w Wietnamie sektor ten nadal stanowi 18\%. Trzecią grupę stanowią kraje przechodzące transformację, o najniższym poziomie PKB per capita (poniżej 5,5 tys. USD), względnie dużym odsetku ludności wiejskiej (powyżej 70\%) i dużym udziale sektora rolnego w tworzeniu $\mathrm{PKB}$, ale z przeciętnym rocznym tempem wzrostu gospodarczego (powyżej 7\%) przewyższającym ten, zaobserwowany w pozostałych krajach ugrupowania - Laos, Kambodża, Myanmar [ASEAN 2016] ${ }^{11}$.

Mając powyższe na uwadze, celem artykułu jest wskazanie zmian poziomu samowystarczalności żywnościowej w wybranych krajach azjatyckich, z uwzględnieniem poziomów produkcji i spożycia artykułów rolno-spożywczych.

\section{Uwagi metodyczne i materiał badawczy}

W celu oceny poziomu samowystarczalności żywnościowej w wybranych krajach Azji posłużono się wskaźnikiem wykorzystywanym w tego typu badaniach i analizach w Unii Europejskiej, a także przez Organizację Narodów Zjednoczonych ds. Wyżywienia i Rolnictwa (FAO) ${ }^{12}$ :

$$
S S R=\frac{\text { produkcja krajowa }}{\text { krajowe zużycie }} \times 100
$$

Miernik ten, wyrażony w procentach, informuje o stopniu pokrycia potrzeb wewnętrznych na danym obszarze (w tym przypadku w zakresie podstawowych grup produktów rolno-spożywczych w poszczególnych krajach członkowskich ASEAN ${ }^{13}$ ) z produkcji krajowej. Im większa jest wartość wskaźnika samowystarczalności, tym możliwości wyżywienia ludności kraju z własnej produkcji są większe.

Badaniem objęto następujące grupy artykułów rolno-żywnościowych: zboża podstawowe, owoce, warzywa, rośliny cukrodajne, oleje roślinne i zwierzęce, mięso wołowe, mięso wieprzowe, mięso drobiowe, baraninę i kozinę, mleko (krowie świeże), jaja oraz ryby i owoce morza.

Do analizy wybrano kraje członkowskie ASEAN: Brunei, Filipiny, Kambodża, Indonezja, Laos, Malezja, Myanmar, Tajlandia, Wietnam ${ }^{14}$. Zakres czasowy analizy, wyznaczony dostępnością danych, dotyczył lat 2003-2013.

\footnotetext{
${ }^{10}$ Przed transformacją gospodarki tych trzech krajów miały charakter typowo surowcowo-rolniczy.

${ }^{11}$ World Bank database, op.cit.

${ }^{12}$ Faostat, http://www.fao.org/faostat/en/\#data/FBS [dostęp: 01.12.2017].

${ }^{13}$ Potrzeby wewnętrzne należy rozumieć jako tzw. zużycie krajowe produktów rolniczych (bez względu na ich pochodzenie). Pojęcie zużycia rozumie się jako spożycie żywności, przetwórstwo na cele niekonsumpcyjne, straty, a w przypadku produkcji roślinnej również to, co zostało przeznaczone na pasze oraz siew. Należy więc mieć na uwadze, że wskaźnik samowystarczalności nie obrazuje bezpośrednio poziomu zaspokojenia potrzeb żywnościowych kraju.

${ }^{14} \mathrm{Z}$ uwagi na brak danych Singapur nie został uwzględniony w badaniu.
} 


\section{Wyniki badań}

Dla większości krajów azjatyckich priorytetem jest osiagnięcie samowystarczalności żywnościowej zakresie zbóż, zwłaszcza ryżu ${ }^{15}$. Jest to dlatego istotne, że w skali światowej z tego ugrupowania pochodzi $28 \%$ produkcji ryżu, a $1 / 3$ powierzchni globalnych upraw tego zboża przypada na jego kraje członkowskie ${ }^{16}$. W strukturze uprawy zbóż w krajach ASEAN ryż stanowi od 60 (Filipiny) do 90\% (Birma). Jednocześnie ugrupowanie to jest jednym z największych światowych konsumentów ryżu (tab. 1). Na mieszkańców tego regionu łącznie przypada nieco ponad 20\% globalnego spożycia ryżu, który w strukturze konsumpcji wszystkich zbóż mieszkańców ASEAN ${ }^{17}$ stanowi średnio 75\% [obliczenia własne na podstawie danych z bazy Faostat]. W latach 2003-2013 średnie spożycie tego zboża na osobę wyniosło od 74 (Brunei w 2003 r.) do 163 kg (Laos w 2005 r.) - tabela 2. Był to poziom kilkunastokrotnie wyższy w porównaniu z USA czy UE [obliczenia własne na podstawie danych z bazy Faostat]. Przyczyn takiego stanu rzeczy należy szukać w uwarunkowaniach kulturowych, politycznych i gospodarczych tego regionu [Dawe 2013]. W zakresie samowystarczalności żywnościowej, znaczne nadwyżki krajowej produkcji ponad krajowe zużycie tego produktu rolno-żywnościowego charakteryzowały Tajlandię i Wietnam (tab. 3). Co prawda względ-

\footnotetext{
${ }^{15}$ Kryzys żywnościowy z lat 2007-2008 ujawnił niejednoznaczność polityki krajowej dedykowanej bezpieczeństwu żywnościowemu w ASEAN. Podczas gdy niektóre kraje skorzystały na rosnących cenach ryżu, sprzedając nadwyżki tego towaru na rynkach zagranicznych (np. Tajlandia, Wietnam), inne jak Filipiny musiały zmierzyć się z szybkim pogorszeniem krajowego bezpieczeństwa żywnościowego [Merzęda-Młynarska 2017]. W kwestii samowystarczalności żywnościowej kraje członkowskie skupiają się głównie na stronie produkcyjnej. W odniesieniu do ryżu wachlarz wykorzystywanych narzędzi jest szeroki. Poza działaniami o charakterze inwestycyjnym (np. nawadnianie) stosuje się m.in. wsparcie cenowe czy dopłaty do środków produkcji (kraje będące importerami netto ryżu - Indonezja, Filipiny, Malezja), zakazy, licencjonowanie, a nawet „blokowane” pewnego wolumenu produkcji (w krajach będących eksporterami netto ryżu: Tajlandia, Wietnam, Kambodża i Laos). Indonezja pełną samowystarczalność w zakresie zbóż (ryż, kukurydza, soja) zamierza osiagnąć do 2017 roku, a w zakresie wołowiny i cukru - do 2019 roku. W Malezji celem jest samowystarczalność w zakresie ryżu na poziomie $90 \%$. Z kolei w Wietnamie odpowiednie działania mają zapewnić utrzymanie wzrostu wydajności produkcji ryżu na poziomie 2,5\% rocznie do 2020 roku [OECD 2017]. Należy podkreślić, że w celu zwiększenia bezpieczeństwa żywnościowego ASEAN współpracuje także na poziomie regionalnym. W 2003 roku z inicjatywy ASEAN, Chin, Japonii i Korei Południowej powstał projekt pilotażowy, tzw. rezerwa ryżowa Azji Wschodniej (ang. East Asia Emergency Rice Reserve), który w 2012 roku przerodził się w ASEAN Plus three Emergency Rice Reserve (APTERR). W ramach tego ostatniego programu 13 krajów zobowiązało się łącznie zgromadzić 787 tys. t ryżu dostępnych dla członków w sytuacjach nadzwyczajnych (np. cyklony, powodzie). To przedsięwzięcie wspierane jest przez System Informacji na rzecz Bezpieczeństwa Żywnościowego (ASEAN AFSIS), mający za zadanie gromadzenie, analizowanie i rozpowszechnianie wśród członków informacji dotyczących bezpieczeństwa żywnościowego [Briones 2011, Belesky 2014].

${ }^{16}$ Faostat, op.cit.

${ }^{17} \mathrm{~W}$ poszczególnych krajach członkowskich ta struktura konsumpcji jest zbliżona. Najwięcej, bo ponad 90\% wszystkich konsumowanych zbóż, przypada na ryż w Birmie i Kambodży, z kolei względnie najmniej spożywają go konsumenci malezyjscy - stanowi on nieco ponad 50\% wszystkich zbóż [obliczenia własne na podstawie danych $\mathrm{z}$ bazy Faostat].
} 


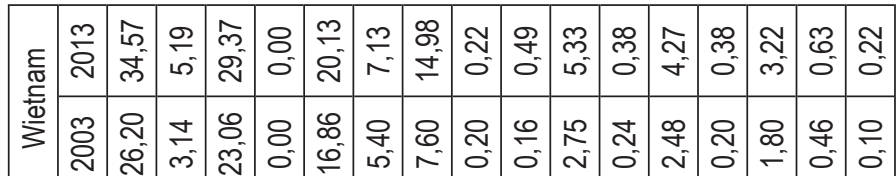

究

元

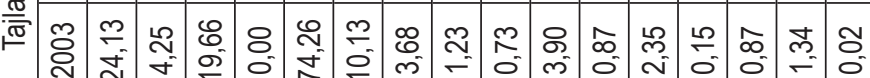

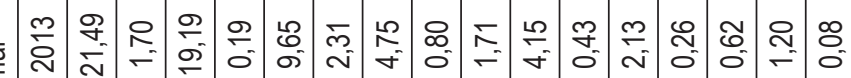

党

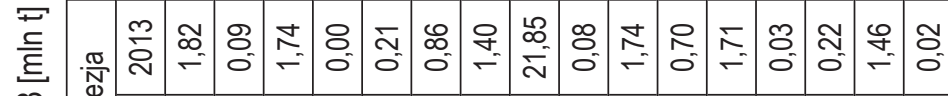

穴

ర్

$\frac{\mathrm{c}}{\mathrm{c}}$

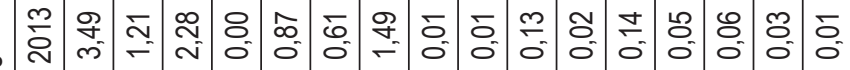

西兽

3

变

등

$\frac{\pi}{\frac{\pi}{2}}$

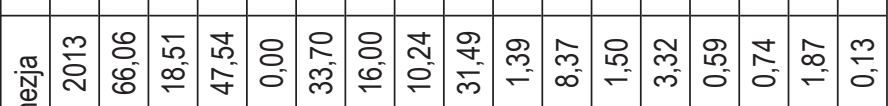

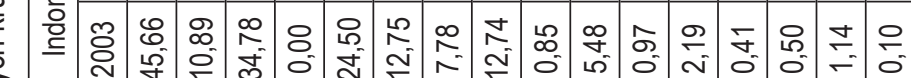

ำ

흠

๘

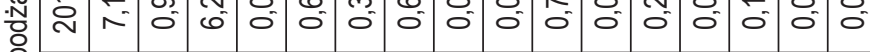

蛋

政

娄

응

\穴

产

든

옥

产

등

ग

들

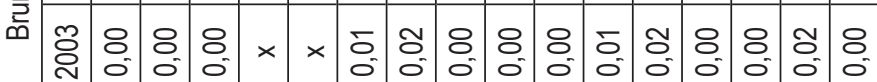

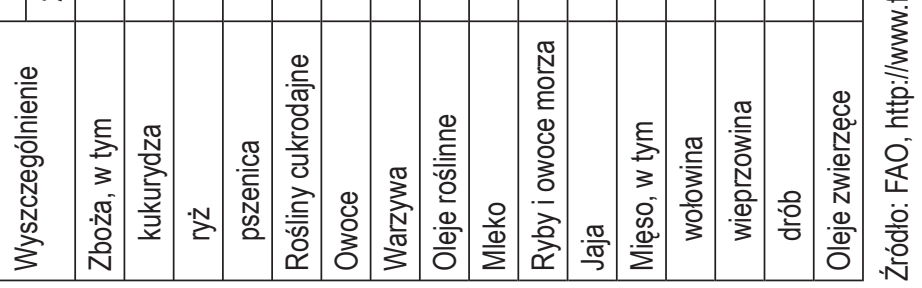




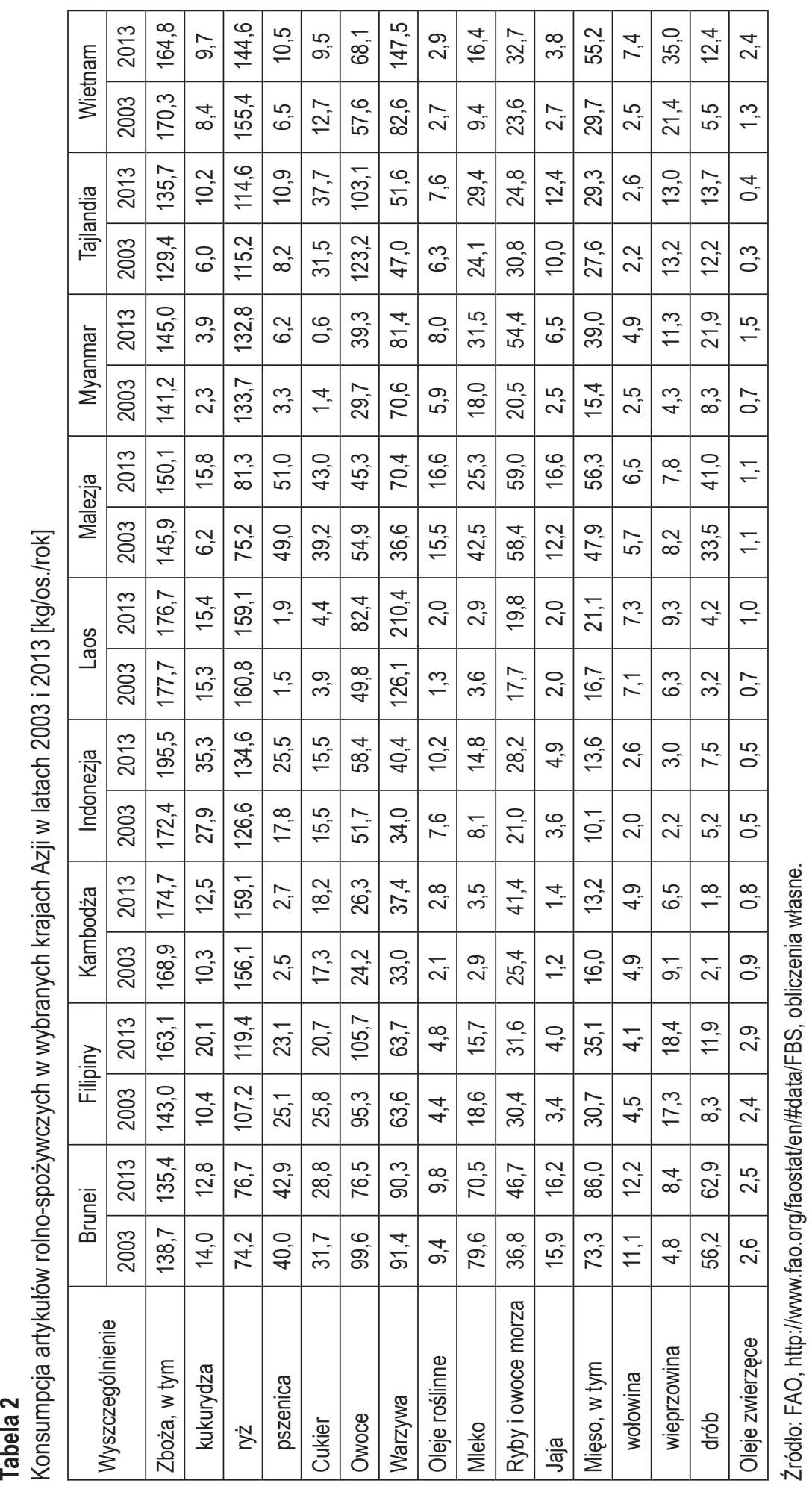




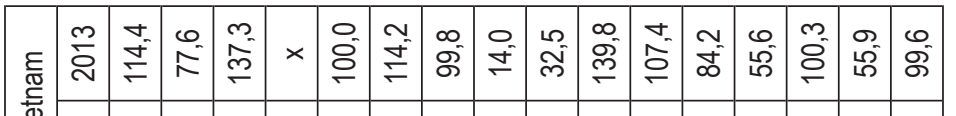

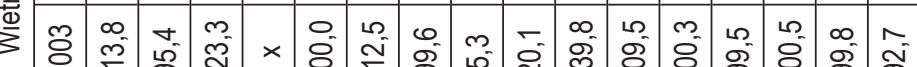

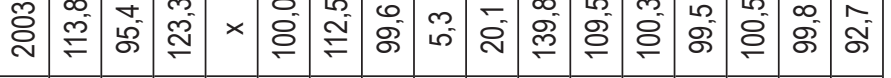

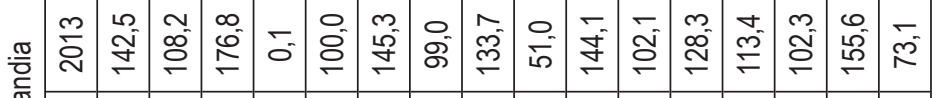

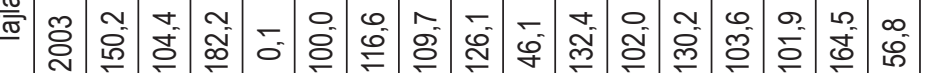

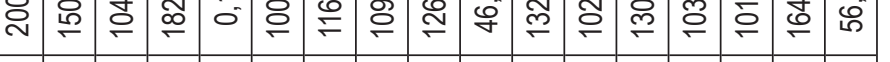

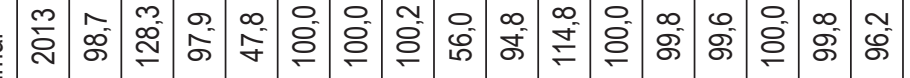
晃

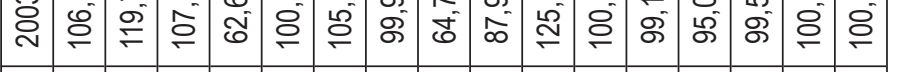

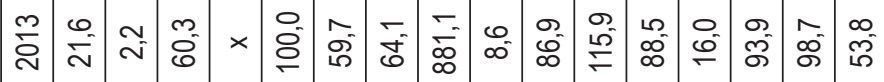

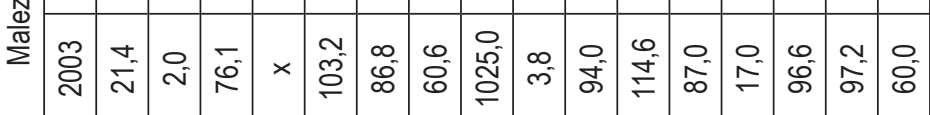
m :

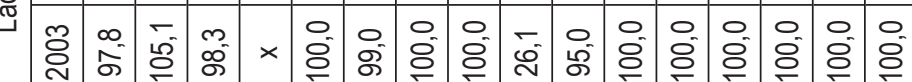

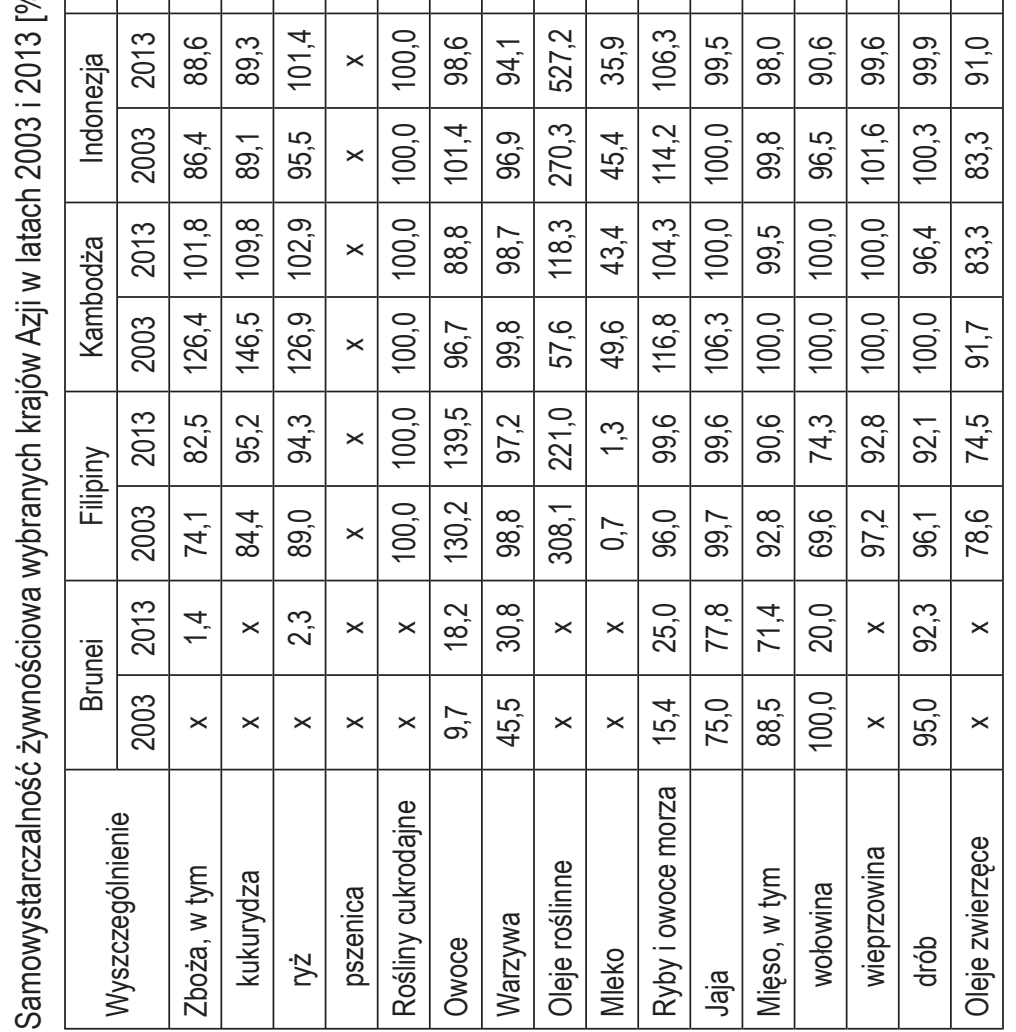

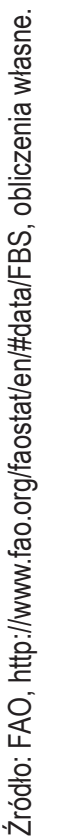


nie większą dynamiką charakteryzowało się spożycie ryżu w tych krajach, wzrost wolumenu produkcji w 2013 roku do poziomu 29,4 mln t w Wietnamie (o 27\%) i $24 \mathrm{mln} \mathrm{t}$ w Tajlandii (o 22\%) pozwolił jednak pokryć zapotrzebowanie krajowe na poziomie znacznie przekraczającym 100\% (tab. 1, 3). Warto zaznaczyć, że oba kraje wraz z Indonezją na przestrzeni analizowanego okresu odpowiadały za blisko $70 \%$ podaży ryżu w całym ugrupowaniu ${ }^{18}$. Ta ostatnia na koniec 2013 roku produkowała 47,5 mln t ryżu. Było to o $35 \%$ więcej niż dekadę wcześniej, co pozwoliło pokryć zapotrzebowanie krajowe w 101,4\%. Warto zaznaczyć, że Indonezja należy do największych producentów ryżu na świecie (na przestrzeni analizowanych lat pochodziło z tego kraju średnio $9 \%$ globalnej podaży) i równocześnie w przypadku tej grupy asortymentowej jest jej importerem netto (w ujęciu wartościowym i ilościowym) [obliczenia własne na podstawie danych z bazy Faostat] ${ }^{19}$. Taki stan rzeczy jest spowodowany z jednej strony przez samych rolników i ich nieoptymalne techniki produkcji ${ }^{20}$ (choć i te ulegają poprawie), a z drugiej przez względnie duże spożycie ryżu przypadające na mieszkańca ${ }^{21}$ - w 2013 roku średnioroczny poziom konsumpcji w ujęciu per capita był wyższy niż w 2003 roku o $6,3 \%$ i wynosił $134,6 \mathrm{~kg}$. W badanym okresie większe spożycie ryżu w skali roku zaobserwowano jedynie wśród mieszkańców Wietnamu i Laosu (tab. 2).

Z kolei, niewielki deficyt w produkcji ryżu (kształtujący się na poziomie 1$-10 \%$ ) w poszczególnych latach zaobserwowano na rynkach pozostałych krajów azjatyckich. Wyjątek stanowiło Brunei, gdzie w 2013 roku zużycie ryżu przekraczało wewnętrzną produkcję o 43 tys. t (wobec 35 tys. t w 2003 r.), a wskaźnik samowystarczalności żywnościowej nie przekroczył 3\%. Rynek malezyjski również charakteryzował się niedoborem podaży ryżu. Produkcja krajowa na przestrzeni lat pokrywała tam zapotrzebowanie wewnętrzne od 60 do $76 \%$. O ile jednak produkcja tej grupy asortymentowej wzrosła w badanym okresie o 15\%, osiagając w 2013 roku poziom ponad 1,7 mln t (tab. 1), o tyle większą dynamikę zaobserwowano w odniesieniu do zużycia (wzrost o 46\%), spowodowaną głównie wzrostem spożycia tego zboża (konsumpcja ryżu stanowiła średnio 85\% zużycia). W 2013 roku przeciętny Malezyjczyk spożywał bowiem 81,25 kg ryżu. Było to o $6 \mathrm{~kg}$ więcej niż w 2003 ro-

\footnotetext{
${ }^{18}$ Oba kraje są zaliczane do największych eksporterów ryżu na świecie, a ich łączny udział w globalnej produkcji tego zboża kształtuje się na poziomie 10\% [obliczenia własne na podstawie danych z bazy Faostat]. ${ }^{19}$ Import występuje głównie z uwagi na konieczność utrzymywania rezerw ryżu na odpowiednim poziomie (1,5-2 mln t). O ile jednak w 2003 roku kształtował się on na poziomie 1,6 mln t, o tyle w 2013 roku import wyniósł $0,47 \mathrm{mln} \mathrm{t}$. W latach 60. i 70. XX wieku indonezyjski import ryżu stanowił odpowiednio 10 i $15 \%$ światowego importu tego zboża.

${ }^{20}$ Około $90 \%$ produkcji ryżu na rynku Indonezji pochodzi z małych gospodarstw rolnych, których powierzchnia nie przekracza 0,8 ha [Lowder i in. 2014, Indonesia Investments 2017].

${ }^{21} \mathrm{~W}$ celu zapewnienia samowystarczalności żywnościowej podejmowane są kroki mające na celu ograniczenie spożycia ryżu wśród mieszkańców, takie jak kampania „jeden dzień w tygodniu bez ryżu” (ang. ,one day no rice”), oraz kampanie promujące konsumpcję innych zbóż [Jakarta Globe 2012].
} 
ku, ale o kilkadziesiąt kilogramów mniej niż przypadało średnio na mieszkańców w pozostałych krajów członkowskich ASEAN (tab. 2).

Warto zwrócić też uwagę na rynek pszenicy, w odniesieniu do której krajowa produkcja praktycznie nie występuje ${ }^{22}$, a rośnie za to jej zużycie generowane przede wszystkim przez zapotrzebowanie na cele konsumpcyjne rosnące wraz ze wzrostem liczby ludności w regionie ${ }^{23}$. Na przestrzeni analizowanych lat spożycie pszenicy w całym ugrupowaniu stanowiło 10-11,5\% wszystkich spożywanych zbóż i stale rosło [obliczenia własne na podstawie danych z bazy Faostat]. Relatywnie najwięcej tego zboża w ujęciu per capita spożywał mieszkaniec Malezji - w 2013 roku było to nieco ponad $51 \mathrm{~kg}$ (o 4\% więcej niż w 2003 r.). Z kolei najbardziej dynamiczny wzrost konsumpcji pszenicy per capita w analizowanym okresie odnotowano w Wietnamie (o 100\%, do poziomu 10,5 kg w 2013 r.) - tabela 2.

Względnie niewielkie niedobory produkcji zaobserwowano na rynkach owoców i warzyw w większości krajów członkowskich ASEAN. Poziom samowystarczalności w przypadku obu grup asortymentowych kształtował się w analizowanym okresie powyżej $90 \%^{24}$, co jest między innymi efektem wzrostu spożycia tych produktów. Największą dynamiką konsumpcji owoców w ujęciu per capita $\mathrm{w}$ analizowanym okresie odnotowano w Laosie. W 2013 roku mieszkaniec tego kraju spożył średnio $82 \mathrm{~kg}$ tej grupy asortymentowej - o 65\% więcej niż w 2003 roku. Było to jednocześnie m.in. ponad trzykrotnie więcej niż w 2013 roku skonsumował obywatel Kambodży, ale o 20 kg mniej niż Filipińczyk (tab. 2). Z kolei w odniesieniu do warzyw najszybciej (niemal dwukrotnie) wzrosło spożycie w ujęciu per capita w Wietnamie (o 72\%) i w Malezji (o 92\%). W tym ostatnim kraju na pogłębienie braku samowystarczalności w przypadku owoców aż o 27 p.p. (największy spadek spośród badanych krajów, z 89 do 60\%) wpływ miał także odnotowany 35\% spadek produkcji do poziomu $0,8 \mathrm{mln} \mathrm{t}$ (konsekwencja suszy) ${ }^{25}$ - tabela 1 . Warto zwrócić też uwagę na Filipiny i Tajlandię, które będąc największymi producentami owoców w ASEAN (ok. 50\%), osiagały najwyższy i znaczy stopień samowystarczalności w zakresie tej grupy asortymentowej - w 2003 roku było to odpowiednio 130 i 116\%, w 2013 roku - 139,5 i 145,3\%.

W całym analizowanym okresie we wszystkich krajach ASEAN występował deficyt w produkcji mleka w porównaniu do krajowego zapotrzebowania (tab. 3). O ile w Birmie poziom samowystarczalności w zakresie tej grupy asortymentowej

\footnotetext{
${ }^{22}$ Zboże było produkowane $\mathrm{w}$ marginalnych ilościach (łączna podaż wyniosła od 123 tys. t w 2003 r. do 190 tys. $t$ w 2013 r., a jedynymi dostawcami były Myanmar i Tajlandia).

${ }^{23}$ Zużycie na cele paszowe także jest na relatywnie wysokim poziomie, chociaż popyt może być osłabiany przez zwiększone użycie substytutów (kukurydza, soja).

${ }^{24}$ Wyjątek w badanych latach stanowiło Myanmar, gdzie produkcja wewnętrzna pokrywała zapotrzebowanie na owoce w $9-18 \%$, a na warzywa $-30-45 \%$.

${ }^{25} \mathrm{~W}$ skali całego ugrupowania Malezja nie jest znaczącym producentem owoców i warzyw. Na przestrzeni lat pochodząca $\mathrm{z}$ tego kraju produkcja stanowiła w przypadku obu grup asortymentowych mniej niż 3\% [obliczenia własne na podstawie danych z bazy Faostat].
} 
wynosił 85-95\%, o tyle w pozostałych krajach nie przekraczał on $50 \%{ }^{26}$. Taki stan rzeczy jest powodowany z jednej strony minimalną produkcją mleka, która w całym ugrupowaniu wzrosła o $80 \%$ na przestrzeni lat (do poziomu $4,8 \mathrm{mln} \mathrm{t})^{27}$, ale w skali świata miała znikome znaczenie (0,6\% w 2013 r.), a z drugiej - rosnącą konsumpcją tej grupy asortymentowej ${ }^{28}$. Pomijając Brunei, gdzie w skali roku spożycie mleka (ale też i produktów mleczarskich) per capita wyniosło od 63 (2012 r.) do $100 \mathrm{~kg}$ (2008 r.), w ASEAN jest stosunkowo niewielkie i w latach 2003-2013 wahało się średnio od 3,2 (Laos) do 26 (Tajlandia) i $36 \mathrm{~kg}$ (Malezji) - tabela 2, podczas gdy w UE czy USA było to odpowiednio ponad 230 i $250 \mathrm{~kg}$ [obliczenia własne na podstawie danych z bazy Faostat].

Warto przyjrzeć się też samowystarczalności w zakresie ryb i owoców morza. Stowarzyszenie Azji Południowo-Wschodniej jako ugrupowanie jest znaczącym producentem $^{29}$ i eksporterem tej grupy asortymentowej na świecie - odpowiada za blisko $17 \%$ jej globalnej podaży i 15\% światowego eksportu [obliczenia własne na podstawie danych z bazy Faostat]. W latach 2003-2013 niedobór w produkcji ryb i owoców morza w porównaniu do krajowego zapotrzebowania zaobserwowano w Brunei, na Filipinach, w Laosie oraz Malezji, co jest przede wszystkim efektem wzrostu zużycia tej grupy asortymentowej zarówno na cele konsumpcyjne, jak i niekonsumpcyjne ${ }^{30}$ (tab. 3). Przy czym największym konsumentem tej grupy asortymentowej w ujęciu per capita w ASEAN była Malezja (średnio $57 \mathrm{~kg}$ ) ${ }^{31}$, za dynamikę wzrostu konsumpcji odpowiadały jednak przede wszystkim Myanmar (2,5-krotny wzrost) oraz Indonezja (wzrost o 36\%). Ta ostatnia jest liderem w zakresie konsumpcji oraz produkcji ryb i owoców morza w skali całego ugrupowania ${ }^{32}$

\footnotetext{
${ }^{26} \mathrm{~W}$ najmniejszym stopniu produkcja krajowa zaspokaja wewnętrzne zużycie na Filipinach i w Malezji (tab. 3).

${ }^{27} Z$ czego $90 \%$ całkowitej podaży mleka przypada na trzy kraje ugrupowania: Myanmar (37\% w 2013 r.), Indonezja (29\%) oraz Tajlandia (23\%).

${ }^{28}$ Wzrost konsumpcji mleka i artykułów mleczarskich jest zasługą nie tylko wzrostu dochodów rozporządzalnych i liczby ludności, ale jest też efektem realizacji rządowych programów promujących konsumpcję mleka w szkołach oraz stopniowego (następującego w ślad za przeobrażeniami gospodarczymi) przejmowania zachodnich wzorców konsumpcyjnych. Według szacunków do 2020 roku konsumpcja tej grupy asortymentowej będzie rosła w tempie 3\% rocznie. Oznaczałoby to, że region Azji Południowo-Wschodniej stanie się jednym z jej największych światowych konsumentów i znacznie zwiększy zapotrzebowanie na import [Black 2016].

${ }^{29}$ Na przestrzeni lat $2003-2013$ wolumen produkcji wzrósł tam o prawie $50 \%$, co było głównie zasługą działań dywersyfikujących hodowane gatunki (w kierunku takich, które cieszą się dużym zainteresowaniem na rynkach zagranicznych) i towarzyszącej im intensyfikacji produkcji. Na dalszy rozwój produkcji będą w przyszłości mieć również wpływ na kwestie związane z ograniczonymi zasobami wody czy powierzchnią ziemi przeznaczanej na przykład na łowiska [OECD-FAO 2017].

${ }^{30}$ Przede wszystkim na pasze oraz przetwórstwo.

${ }^{31} \mathrm{~W}$ ujęciu krajowym zaś liderem jest Indonezja. Tam spożycie per capita jest stosunkowo małe (24,9 kg), ale liczba ludności powoduje, że konsumpcja ryb i owoców morza stanowi około 1/3 całej konsumpcji ASEAN [obliczenia własne na podstawie danych z bazy Faostat].

${ }^{32}$ Indonezja jest też drugim po Chinach największym producentem ryb i owoców morza na świecie.
} 
(odpowiednio średnio po 30\%), a w analizowanych latach była samowystarczalna w odniesieniu do tej grupy asortymentowej (tab. 2 i 3).

Także w Indonezji i Malezji zaobserwowano największe nadwyżki podaży olejów roślinnych - w 2013 roku wskaźnik samowystarczalności w tych krajach wyniósł odpowiednio 527 i 881\% (tab. 3). Oba kraje łącznie w 2013 roku wyprodukowały 53,3 mln t olejów roślinnych ${ }^{33}$, co stanowiło ponad $91 \%$ w skali całego ugrupowania i 32\% w skali światowej. Było to też prawie dwukrotnie więcej niż na początku badanego okresu ${ }^{34}$ (tab. 1). Nie bez znaczenia dla wysokiego poziomu samowystarczalności w tym zakresie odnotowanego w Indonezji i Malezji jest to, że oleje roślinne (zwłaszcza olej palmowy) w strukturze ich produkcji rolno-spożywczej stanowiły w 2013 roku odpowiednio 20 i blisko 65\% [FAO-OECD 2017]. Jednocześnie zwiększyło się też zużycie olejów roślinnych o blisko 27\% w Indonezji (5,9 mln t w 2013 r.) i o 65\% w Malezji (2,5 mln t w 2013 r.), przy czym w znacznym stopniu było ono efektem wzrostu zużycia olejów roślinnych na cele przemysłowe (średnio 60-75\% całkowitego zużycia).

Stopień samowystarczalności krajów członkowskich ASEAN w zakresie roślin cukrodajnych kształtował się na stabilnym, około 100-procentowym poziomie (tab. 3). Za wolumen podaży całego ugrupowania na poziomie ponad $197 \mathrm{mln} \mathrm{t}$ (2013) w 94\% odpowiadały łącznie cztery kraje: Tajlandia $(50,8 \%)$, Indonezja $(17,1 \%)$, Filipiny $(16,2 \%)$ oraz Wietnam $(10,2 \%)$. Na tę czwórkę przypadało także ponad 90\% zużycia roślin cukrodajnych w skali ASEAN, a największą jego część stanowiło „przetwórstwo” (na konsumpcję i produkcję bioetanolu). Na przestrzeni lat przeznaczano na nie średnio od $83 \%$ całego krajowego zużycia w Wietnamie do $100 \% \mathrm{w}$ Indonezji. W tym miejscu należy podkreślić, że ASEAN jest drugim, po Indiach, największym producentem cukru w Azji, a w ujęciu globalnym odpowiada za 9-10\% podaży, dostarczając średnio $17 \mathrm{mln}$ t tej grupy asortymentowej (z czego $10 \mathrm{mln} t$ pochodzi z Tajlandii). Jednocześnie w skali roku konsumuje się tam średnio $14 \mathrm{mln} \mathrm{t}$ cukru, a na jednego mieszkańca tego ugrupowania przypada od $1 \mathrm{~kg}$ w Birmie przez $15 \mathrm{~kg}$ w Indonezji do $43 \mathrm{~kg}$ cukru w Malezji (tab. 2) [obliczenia własne na podstawie danych z bazy Faostat]. Znaczna część wzrostu konsumpcji cukru $\mathrm{w}$ regionie ma miejsce $\mathrm{w}$ czterech krajach będącymi głównymi producentami tego towaru i wynika przede wszystkim z rosnącego poziomu dochodów rozporządzalnych mieszkańców oraz wzrostu liczby ludności.

W odniesieniu do mięsa tylko Laos osiagał produkcję na poziomie zaspokajającym zużycie w zakresie wszystkich jego rodzajów, przy czym w skali regionu,

\footnotetext{
${ }^{33} \mathrm{Z}$ czego ponad $85 \%$ stanowił olej palmowy.

${ }^{34}$ Wzrost produkcji nastapił $\mathrm{w}$ wyniku przekształcenia terenów zalesionych $\mathrm{w}$ grunty do uprawy palmy olejowej. Co prawda zmiany te przyczyniły się do zwiększenia dochodów osób zatrudnionych w rolnictwie, ale nie pozostały one bez wpływu na środowisko naturalne. Badania pokazują, że w latach 1990-2010 17\% nowych plantacji palmy olejowej w Malezji i 63\% w Indonezji powstało kosztem bogatych w bioróżnorodność lasów tropikalnych (deforestacja) [Koh i in. 2011, Gunarso i in. 2013], a na dodatek przyczyniło się do zwiększenia emisji dwutlenku węgla w tym sektorze [Carlson i in. 2012].
} 
dostarczając 142 tys. t, kraj ten odpowiadał jedynie za niecały 1\% produkcji mięsa ogółem (tab. 1 i 3). Warto podkreślić, że w produkcji mięs w ASEAN przez lata dominowała wieprzowina (ok. 44\% w 2003 r.), a jej największymi dostawcami były i nadal pozostają Wietnam (średnio $40 \%$ ) oraz Filipiny $(22 \%$ ), z których łącznie na koniec badanego okresu pochodziło 4,9 mln t (tab. 1). Oba kraje należą też do największych konsumentów tego rodzaju mięsa, zarówno w ujęciu per capita, jak i krajowym. W przeciąu dekady spożycie wieprzowiny wzrosło odpowiednio o $63 \%$ (do $35 \mathrm{~kg} / \mathrm{os} . /$ rok) i niemal o $80 \%$ w Wietnamie $(3,2 \mathrm{mln}$ t) i o $6 \%$ (do $18,4 \mathrm{~g} /$ /os./rok) oraz o $27 \%$ na Filipinach (do $1,8 \mathrm{mln}$ t) - tabela 2 . W zakresie tej grupy asortymentowej poziom samowystarczalności żywnościowej w krajach członkowskich był zróżnicowany i kształtował się w 2013 roku od 92,8 (Filipiny) do 102,3\% (Tajlandia) - tabele 2 i 3.

Obecnie dynamicznie rozwija się produkcja mięsa drobiowego stymulowana szybkim rozwojem społeczno-gospodarczym krajów ASEAN i podążającym za nim rosnącym popytem na ten rodzaj mięsa. Systematyczny wzrost zużycia mięsa drobiowego na cele konsumpcyjne w ostatnich latach w poszczególnych krajach ASEAN, niejednokrotnie szybszy niż wzrost produkcji, wywołał negatywne zmiany w poziomie samowystarczalności w tym zakresie (tab. 1, 2 i 3). Taką sytuację zaobserwowano w Kambodży, Indonezji, Wietnamie i na Filipinach. Najszybciej konsumpcja rosła w Birmie i Wietnamie - w 2013 roku w ujęciu per capita spożywano tam odpowiednio o $162(21,9 \mathrm{~kg})$ i 125\% (12,4 kg) więcej niż dekadę wcześniej, przy czym nadal było to o kilkadziesiąt kilogramów mniej niż w Malezji (44 kg), charakteryzującej się najwyższym poziomem konsumpcji tej grupy asortymentowej w skali całego ugrupowania (tab. 2) ${ }^{35}$. Łącznie kraje ASEAN wyprodukowały w 2013 roku 7,8 mln t mięsa drobiowego - o 60\% więcej niż w 2003 roku - z czego $77 \%$ tej produkcji miało miejsce w Indonezji (24\%), Tajlandii $(18,9 \%)$, Malezji $(18,7 \%)$ i Birmie $(15,45 \%)$. Jednocześnie wolumen produkcji tego rodzaju mięsa zwiększył swój udział w globalnej podaży do $7,2 \%$.

\section{Podsumowanie}

Z przeprowadzonej analizy samowystarczalności żywnościowej wynika, że kraje członkowskie ASEAN charakteryzuje zróżnicowany jej stopień w zakresie podstawowych produktów rolno-żywnościowych.

Wskaźnik samowystarczalności w odniesieniu do ryżu w Birmie, Indonezji, Laosie oraz na Filipinach oscylował w granicach 90-100\%. Znaczną nadprodukcję od-

\footnotetext{
${ }^{35}$ Średnia ilość spożywanego w ciągu roku mięsa drobiowego per capita w Malezji jednocześnie była trzykrotnie większa niż średnia światowa (w 2013 r. - $15 \mathrm{~kg}$ ). Taki stan rzeczy wynika nie tylko z rosnących dochodów obywateli, ale też z substytucji droższej wołowiny względnie tańszym mięsem drobiowym oraz licznej muzułmańskiej populacji (ok. 60\%) [USDA 2014].
} 
notowano tylko w Tajlandii i Wietnamie. Jednocześnie wszystkie kraje tego regionu $\mathrm{w}$ badanych latach osiagały produkcję roślin cukrodajnych na poziomie zaspokajającym zużycie tej grupy produktów.

Zaobserwowano też, że wzrost zamożności mieszkańców krajów członkowskich ASEAN stymulowany reformami gospodarczymi oraz włączeniem się w wymianę międzynarodową tych krajów przełożył się na zmiany we wzorcach konsumpcji żywności. Zmiany te polegają na wzroście spożycia produktów pochodzenia zwierzęcego. Zarówno na rynku mleka, jak i mięsa za dynamiczny wzrost konsumpcji w ASEAN w ujęciu per capita odpowiadały Myanmar, Wietnam i Indonezja. Nadal jednak w porównaniu do UE i USA jej poziom był kilku- i kilkunastokrotnie niższy. Jednocześnie podczas gdy na rynku mięsa w ślad za konsumpcją rosła rodzima produkcja - co pozwoliło krajom ASEAN utrzymać względnie wysokie wskaźniki samowystarczalności żywnościowej w tym zakresie - na rynku mleka odnotowano największe niedobory produkcji. W efekcie, poza Birmą, poziom samowystarczalności w odniesieniu do tej grupy asortymentowej nie przekraczał w krajach członkowskich $50 \%$.

\section{Literatura}

ARNST R., 2009: Business as usual: Responses within ASEAN to the food crisis, Occasional paper 4, Manila: Focus on the Global South, http://focusweb.org/pdf/occasionalpaper4. pdf [dostęp: 20.12.2017].

Association of South-East Asian Nations, ASEAN, 2016: Statistical Yearbook 2016, Jakarta.

BAER-NAWROCKA A., 2014: Zmiany $w$ spożyciu $i$ stopniu samowystarczalności żywnościowej w Unii Europejskiej, Prace Naukowe Uniwersytetu Ekonomicznego we Wrocławiu. Agrobiznes. Problemy Ekonomiczne i Społeczne 360, 19-27.

BELESKY P., 2014: Regional Governance, Food Security and Rice Reserves in East Asia, Global Food Security 3 (3-4), 167-173, http://dx.doi.org/10.1016/j.gfs.2014.09.002

BELLO A.L., 2005: Ensuring Food Security - A Case for ASEAN Integration, Asian Journal of Agriculture and Development 2 (1-2), 87-108.

BLACK E., 2016: Got milk? Demand for Dairy Soars in Southeast Asia, http://sea-globe. com/got-milk-demand-dairy-soars-southeast-asia [dostęp: 11.11.2017].

BRIONES R.H., 2011: Regional Cooperation for Food Security: The Case of Emergency Rice Reserves in the ASEAN Plus Three, ADB Sustainable Development Working Paper Series 18, Asian Development Bank, Philippines.

CARLSON K.M., CURRAN L.M., ASNER G.P., PITTMAN A.M., TRIGG S.N., ADENEY J.M., 2012: Carbon emissions from forest conversion by Kalimantan oil palm plantations, Nature Climate Change 3 (3), 283-287, doi 10.1038/nclimate1702

CLAPP J., 2017: Food self-sufficiency: Making sense of it, and when it makes sense, Food Policy 66, 88-96.

DAWE D., 2013: Geographic determinants of rice self-sufficiency in Southeast Asia, ESA-FAO Working Paper 13-03. 
Food and Agriculture Organization UN, FAO, 2008: An Introduction to the Basic Concepts of Food Security, Food Security Information for Action. Practical Guides, EC-FAO Food Security Programme, Rome, http://www.fao.org/docrep/013/a1936e/al936e00.pdf [dostęp: 11.01.2018].

Food and Agriculture Organization UN, FAO, 2017: The State of Food Security and Nutrition in the World. Building Resilience for Peace and Food Security, Rome.

GULBICKA B., 2009: Problemy wyżwienia w krajach rozwijajacych się, [w:] Program wieloletni 2005-2009. Ekonomiczne i społeczne uwarunkowania rozwoju polskiej gospodarki żywnościowej po wstapieniu Polski do Unii Europejskiej, Instytut Ekonomiki Rolnictwa i Gospodarki Żywnościowej - Państwowy Instytut Badawczy, Warszawa.

GULBICKA B., KWASEK M., OBIEDZIŃSKA A., 2015: Z badań nad rolnictwem społecznie zrównoważonym (33). Analiza bezpieczeństwa żywnościowego Polski, Instytut Ekonomiki Rolnictwa i Gospodarki Żywnościowej - Państwowy Instytut Badawczy, Warszawa.

GUNARSO P., HARTOYO M.E., AGUS F., KILLEEN T., 2013: Oil Palm and Land Use Change in Indonesia, Malaysia and Papua New Guinea, Round Table on Sustainable Palm Oil (RSPO), Singapore, http://dx.doi.org/10.1787/9789264272392-en

Indonesia Investments, 2017: Rice, https://www.indonesia-investments.com/business/commodities/rice/item183? [dostęp: 12.12.2017].

Jakarta Globe, 2012: One Day No Rice to Become National Program, http://jakartaglobe. id/archive/one-day-no-rice-to-become-national-program [dostęp: 15.12.2017].

KAPUSTA F., 2016: Bezpieczeństwo żywnościowe Polski i jej mieszkańców w okresie przedakcesyjnym i po akcesji do Unii Europejskiej, Ekonomia XXI wieku 4 (12), 69-86.

KOH L.P., MIETTINEN J., LIEW S.C., GHAZOUL J., 2011: Remotely sensed evidence of tropical peatland conversion to oil palm, Proceeding of the National Academy of Sciences of the United States of America, Stanford University 108 (12), 5127-5132, https://doi.org/10.1073/pnas.1018776108

KRACIUK J., 2015: Bezpieczeństwo żywnościowe z perspektywy krajów słabo i wysoko rozwiniętych, Roczniki Naukowe Stowarzyszenia Ekonomistów Rolnictwa i Agrobiznesu 17 (3), 205-209.

KWASEK M., 2009: Tendencje $w$ spożyciu żywności $w$ krajach rozwijajacych się na tle rozwoju społeczno-gospodarczego, Publikacje Programu Wieloletniego 2005-2009 IERiGŻ 123.

LOWDER S.K., SKOET J., SINGH S., 2014: What do we really know about the number and distribution of farms and family farms worldwide?, Background Paper for The State of Food and Agriculture, ESA-FAO Working Paper 14-02.

MALCHAR-MICHALSKA D., 2012: Wpływ kryzysu żywnościowego na wykorzystanie ograniczeń eksportowych $w$ handlu międzynarodowym surowcami rolnymi, [w:] J. Rymarczyk, M. Domiter, W. Michalczyk (red.), Handel i inwestycje w semiglobalnym otoczeniu, Prace Naukowe Uniwersytetu Ekonomicznego we Wrocławiu 267, t. 2, 33-44.

MAŁYSZ J., 2008: Bezpieczeństwo żywnościowe strategiczna potrzeba ludzkości, AlmaMer, Warszawa.

MERZĘDA-MŁYNARSKA K., 2017: Food Security Governance in the Southeast Asia Region: from National to Regional Governance, Historia i Polityka 20 (27), 31-48, http:// dx.doi.org/10.12775/HiP.2017.010 
MIKUŁA A., 2012: Bezpieczeństwo żywnościowe Polski, Roczniki Ekonomii Rolnictwa i Rozwoju Obszarów Wiejskich 99 (4), 38-48.

NOSECKA B., KRASOWICZ S., PAWLAK K., KITA K., ZAREMBA Ł., 2012: Czynniki konkurencyjności sektora rolno-żywnościowego we współczesnym świecie, Raport PW 54, Instytut Ekonomiki Rolnictwa i Gospodarki Żywnościowej - Państwowy Instytut Badawczy, Warszawa.

Organisation for Economic Co-operation and Development, OECD, 2017: Building Food Security and Managing Risk: A Focus on Southeast Asia, 2017, OECD Publishing, Paris.

Organisation for Economic Co-operation and Development, Food and Agriculture Organization UN, OECD-FAO, 2017: Agricultural Outlook 2017-2026, OECD Publishing, Paris.

SAPA A., 2010: Bezpieczeństwo żywnościowe w krajach rozwijajacych się, Roczniki Ekonomiczne Kujawsko-Pomorskiej Szkoły Wyższej w Bydgoszczy 3, 231-244.

US Department of Agriculture, USDA, 2014: International Egg And Poultry Review 17 (14), http://search.ams.usda.gov/MNDMS/2014/04/PY20140408WIntlPoultryandEgg.pdf [dostęp: 11.12.2017].

ŻYŁA A., 2013: Charakterystyka azjatyckiego modelu rozwoju gospodarczego wświetle teorii oraz doświadczeń krajów zaliczanych do pierwszej i drugiej generacji „azjatyckich tygrysów”, Prace Naukowe Uniwersytetu Ekonomicznego we Wrocławiu 315, 459-470.

\title{
Changes in food self-sufficiency of selected Asian countries
}

\begin{abstract}
The aim of the article is to discuss changes food self-sufficiency in ASEAN countries, defined as the proportion of domestic consumption to domestic production. With regard to rice, which due to historical, geographical and cultural conditions is the focus of the governments of all member countries in ASEAN, only in Thailand, Vietnam and Cambodia the self-sufficiency rate exceeded $100 \%$. In turn, in all Member States, production has met the needs of the internal markets in the field of sugar crops. Relatively biggest shortages of production were noticed for milk. An increase in the consumption of agri-food products of both vegetable origin and animal products was observed. But the consumption of the latter was more dynamic. The growing demand for products of animal origin is the result of rapid socio-economic development of ASEAN countries, followed by changes in the structure of food consumed towards patterns observed in developed countries.
\end{abstract}

Key words: food self-sufficiency, agri-food consumption, rice, ASEAN JEL classification: D12, Q11, O10, O57

Otrzymano: 10 lutego 2018 r. / Zaakceptowano: 30 marca 2018 r. Received: 10 February / Accepted: 30 March 2018 